\title{
Antiviral Activity of Indonesian Medicinal Plants against Hepatitis B Virus
}

\author{
Tutik Sri Wahyuni ${ }^{1,2, *}$, Adita Ayu Permanasari ${ }^{2}$, Aty Widyawaruyanti ${ }^{1,2}$, Hak Hotta ${ }^{3,4}$, Chie Aoki-Utsubo ${ }^{4}$, \\ Achmad Fuad Hafid ${ }^{1,2}$
}

Tutik Sri Wahyuni ${ }^{1,2, *}$, Adita

Ayu Permanasari ${ }^{2}$, Aty

Widyawaruyanti ${ }^{1,2}$, Hak Hotta ${ }^{3,4}$,

Chie Aoki-Utsubo4, Achmad Fuad Hafid $^{1,2}$

\section{'Department of Pharmacognosy and Phytochemistry, Faculty of Pharmacy, Universitas Airlangga, Jl. Mulyorejo, Surabaya 60115, INDONESIA. \\ 2Institute of Tropical Disease, Universitas Airlangga, Jl. Mulyorejo, Surabaya 60115, INDONESIA. \\ ${ }^{3}$ Faculty of Clinical Nutrition and Dietetics, Konan Women's University, 6-2-23 Morikita- machi, Higashinada-ku, Kobe 658-0001, JAPAN. \\ ${ }^{4}$ Department of Public Health, Kobe University Graduate School of Health Sciences, 7-10-2, Tomogaoka, Suma-ku, Kobe 654-0142, JAPAN.}

\section{Correspondence \\ Tutik Sri Wahyuni}

Department of Pharmacognosy and Phytochemistry, Faculty of Pharmacy, Universitas Airlangga, Surabaya 60286 INDONESIA

Phone no: +62 31 5033710;

Fax: +62 315020514

E-mail: tutik-s-w@ff.unair.ac.id; wahyuni. tutiksri@yahoo.com

History

- Submission Date: 07-05-2020;

- Review completed: 20-05-2020;

- Accepted Date: 05-06-2020.

DOI : 10.5530/pj.2020.12.157

Article Available online http://www.phcogj.com/v12/i5

\section{Copyright}

(C) 2020 Phcogj.Com. This is an openaccess article distributed under the terms of the Creative Commons Attribution 4.0 International license.

\section{ABSTRACT}

Background: Hepatitis B virus (HBV) infects more than 300 million people globally and is a common cause of liver cancer. Current therapy using reverse transcriptase inhibitors require long-term treatment and the potential risk of development of drug-resistant viruses remains an important issue to be considered. Hence, the development of new drugs is critical. Traditional medicinal plants used for the treatment of infectious diseases may provide a viable option for the discovery of anti-HBV drug candidates. Objective: This study examined anti-HBV activity of 31 kinds of Indonesian plants. Materials and Methods: Crude extracts of various part of plants, leaves and stem, were obtained using dichloromethane and ethanol solvent. The effect on viral entry was examined by determining levels of HBsAg expression in the supernatants of HBV-infected HepG2-NTCP cells by ELISA. The effect on HBV replication was determined by measuring HBV DNAs amounts in Hep38.7-Tet cells by quantitative real-time PCR. Results: The extracts of Phyllantus niruri leaves and Curcuma xanthorrhiza showed reduction of strong HBsAg production from HepG2-NTCP cells with $I_{50}$ values of 170.48 and $270.51 \mu \mathrm{g} / \mathrm{mL}$, respectively. Treatment of HepAD38.7-Tet cells with $P$. niruri and $C$. xanthorhiza at the highest concentration while avoiding cytotoxicity reduced extracellular HBV DNA levels by $70 \%$ and 30 $\%$ of the untreated control respectively. Conclusion: $P$. niruri inhibited both the entry and HBV replication, thus $P$. niruri is a promising candidate for anti-HBV drug development.

Key words: Hepatitis B Virus, Phyllanthus niruri, Curcuma xanthorhiza, Medicinal plants.

\section{INTRODUCTION}

Hepatitis B Virus (HBV), a member of the Hepadnaviridae family, is an enveloped virus with partially double-stranded circular DNA genome that attacks the liver and causes both acute and chronic HBV infections. Chronic HBV infections result in liver cirrhosis and hepatocellular carcinoma (HCC). ${ }^{1,2}$ It has been estimated that approximately 257 million people are living with chronic hepatitis $\mathrm{B}$ infection resulting in circa 887000 deaths annually. ${ }^{3}$ Transmission of HBV infection occurs when an uninfected person comes into contact with infected blood and/or body fluids (e.g., semen, vaginal secretions, etc) through sexual activity, sharing of personal items, contaminated medical equipment and mother to child transmission during birth. ${ }^{4}$

To support HBV prevention, a HBV vaccine has been developed, which is safe, and effective as a routine prophylactic by inducing the appropriate immune response in the host. ${ }^{5}$ In contrast, once an infection has occurred, the current antiviral treatments for the suppression of HBV replication are used. Interferon (IFNs) and nucleos(t)ide analogues (NAs) have been used and demonstrated to prevent cirrhosis, liver failure and HCC which is caused by $\mathrm{HBV}$ infection. ${ }^{6}$ However, the longterm treatment with (NAs) and interferons is associated with an increased risk of side effects and potential drug resistance. ${ }^{7}$ Therefore, it is necessary to develop a new theraphy or alternative medicine against HBV infection.

Medicinal plants are rich in various secondary metabolites that have been used to cure several kinds of human disease. It is interesting that about $80 \%$ of the active ingredient which have been isolated from plants indicate a positive correlation between modern and traditional therapeutic uses. Some of these plants, such as Curcuma longa Linn, ${ }^{9}$ Ganoderma lucidum, ${ }^{10}$ Acanthus ilicifolius $L,{ }^{11}$ and Oenanthe javanica ${ }^{12}$ have been reported to exhibit anti-HBV activity. Several compounds (periglaucines A-D, norruffscine, (-)-8-oxotetrahydropalmatine) isolated from Pericampylus glaucus, showed antiHBV activity on HepG2.2.15 cell line in vitro. Compounds of 8-oxotetrahydropalmatine could inhibit HBsAg secretion with an 50\% inhibition concentration $\left(\mathrm{IC}_{50}\right)$ value of $0.14 \mathrm{mM}(\mathrm{SI}=22.4)$. It has also been reported that piperine and guineesine, isolated compounds of Piper longum, exhibit inhibitory activity suppressing the secretion of $\mathrm{HBsAg}$ and $\mathrm{HBeAg}$ with $\mathrm{IC}_{50}$ values of 0.15 and 0.05 $\mathrm{mM}$ for $\mathrm{HBsAg}$, and 0.14 and $0.05 \mathrm{mM}$ for $\mathrm{HBeAg}$, respectively. ${ }^{13}$ Our previous study was reported Cananga odorata possessed a strong anti-HBV activity both in HepG2-NTCP and Hep38.7-Tet cells which indicated the action of extract in the entry and post entry steps (replication) of HBV life cycle. ${ }^{14}$ In this study, we screened 31 samples of Indonesian medicinal plants for anti-HBV activity by two invitro assays to assess the effect on the viral entry and replication.
Cite this article: Wahyuni TS, Permanasari AA, Widyawaruyanti A, Hotta $H$, Aoki-Utsubo C, Hafid. Antiviral Activity of Indonesian Medicinal Plants against Hepatitis B Virus. Pharmacogn J. 2020;12(5):1108-14 


\section{MATERIALS AND METHODS}

\section{Plant material}

A total of 37 plants were collected from the National Botanical Garden of Balikpapan Kalimantan Timur and Malang, East Java, Indonesia (Table 1). Plants were identified by an experienced Botanist at the National Botanical Garden, Malang and all leaves were dried at room temperature inside away from direct sunlight.

\section{Cell lines and virus}

HepG2-NTCP cells ${ }^{15}$ were used to assess the antiviral effect on the viral entry. These cells are known to express sodium taurocholate co-transporting polypeptide (NTCP) that has been identified as a functional receptor for HBV. Post-entry inhibition was analyzed using Hep38.7-Tet cells that expressed viral HBV pgRNA under tetracycline provision. The viruses that were produced from Hep38.7-Tet were used to infect HepG2-NTCP cells. To enhance the infection process, PEG was added during virus infection. The HepG2-NTCP cells were cultivated using Dulbecco's Modified Eagle Medium/Nutrient Mixture F12 with GlutaMAX (Thermo Fisher Scientific, Carlsbad, CA), supplemented with 10\% FBS, $10 \mathrm{mM}$ HEPES, $5 \mu \mathrm{g} / \mathrm{ml}$ insulin (Fujifilm Wako), 100

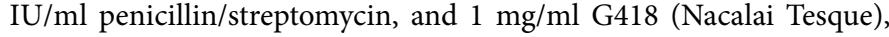
while the Hep38.7-Tet was grown in basal culture medium with a

Table 1: Medicinal plants tested for anti-HBV activity in HepG2-NTCP cell culture.

\begin{tabular}{|c|c|c|c|}
\hline No & Species Name & Code & Family \\
\hline \multicolumn{4}{|c|}{ Dichloromethane extract of leaves (Balikpapan sample) } \\
\hline 1 & Melicope glabra (Syn M. pinnata) & BP01 & Rutaceae \\
\hline 2 & Luvunga scandens (Roxb.) Wight & $\mathrm{BP} 02$ & Rutaceae \\
\hline 3 & Artocarpus sericicarpus & BP03 & Moraceae \\
\hline 4 & Artocarpus dadah Miq. & BP05 & Moraceae \\
\hline 5 & Scorodocarpus borneensis & BP06 & Olacaceae \\
\hline 6 & Eusideroxylon zwageri & BP07 & Lauraceae \\
\hline 7 & Fagraea racemosa & BP08 & Loganiaceae \\
\hline 8 & Pternandra galeata & BP09 & Melastomataceae \\
\hline 9 & Fordia splendidissima & BP11 & Fabaceae \\
\hline 10 & Aglaia lawii & BP13 & Meliaceae \\
\hline 11 & Gonocaryum littorale & BP15 & Icacinaceae \\
\hline 12 & Orophea hexandra & BP16 & Lauraceae \\
\hline 13 & Gymnacranthera farguhariana & BP18 & Lauraceae \\
\hline 14 & Alseodaphne elmeri & BP19 & Lauraceae \\
\hline 15 & Neolitsea cassiaefolia & BP20 & Lauraceae \\
\hline 16 & Vernonia arborea & BP21 & Asteraceae \\
\hline 17 & Ficus geocaris & BP22 & Moraceae \\
\hline \multicolumn{4}{|c|}{ Dichloromethane extract of stem bark (Balikpapan Sample) } \\
\hline 18 & Melicope glabra (Syn M. pinnata) & SB01 & Rutaceae \\
\hline 19 & Luvunga scandens (Roxb.) Wight & SB02 & Rutaceae \\
\hline 20 & Artocarpus sericicarpus & SB03 & Moraceae \\
\hline 21 & Artocarpus anisophyllus & SB04 & Moraceae \\
\hline 22 & Scorodocarpus borneensis & SB05 & Olaccaceae \\
\hline 23 & Alstonia angustiloba & SB07 & Apocynaceae \\
\hline 24 & Alseodaphne elmeri & SB08 & Lauraceae \\
\hline 25 & Ficus geocaris & SB09 & Moraceae \\
\hline \multicolumn{4}{|c|}{ Ethanol extract (East Java Sample) } \\
\hline 26 & Ruta angustifolia (leaves) & W1 & Rutaceae \\
\hline 27 & Phyllantus niruri (herbs) & W2 & Euphorbiaceae \\
\hline 28 & Curcuma domestica (Rhizome) & W3 & Zingiberaceae \\
\hline 29 & Curcuma xanthoriza (Rhizome) & W4 & Zingiberaceae \\
\hline 30 & Curcuma heyneana (Rhizome) & W5 & Zingiberaceae \\
\hline 31 & Zingiber officinale (Rhizome) & W6 & Zingiberaceae \\
\hline
\end{tabular}

composition similar to that used for the HepG2-NTCP cells, but with the addition of $400 \mu \mathrm{g} / \mathrm{ml} \mathrm{G418}$ and $400 \mathrm{ng} / \mathrm{ml}$ tetracycline (Fujifilm Wako). All cells were maintained at $37^{\circ} \mathrm{C}$ and $5 \% \mathrm{CO} 2$ atmosphere in a humidified incubator.

\section{Plant extraction}

Several different solvents (ethanol 80\%, hexane, and dichloromethane) were used to extract from the leaf and stem samples. The leaves were extracted using $n$-hexane and ethanol $80 \%$. Meanwhile, the residue from the $n$-hexane extract underwent a further extraction process using dichloromethane (DCM). In this study we used dichloromethane extracts from samples collected in Balikpapan, Indonesia while ethanol $80 \%$ extract was used for the East Java collection. All extracts were dissolved in dimethyl sulfoxide (DMSO) at a concentration of $100 \mathrm{mg} /$ $\mathrm{ml}$ and then stored at $-30^{\circ} \mathrm{C}$.

\section{HBV entry inhibition screening}

The HepG2-NTCP were seeded in a 24 well plate for 24 hours before the assay was performed. Cells were inoculated with HBV in the presence of a single concentration of plant extract $(100 \mu \mathrm{g} / \mathrm{mL})$ for the screening assay. The activity of plant extract was examined at different concentrations $\left(400 ; 200 ; 100\right.$; and $50 \mu \mathrm{g} / \mathrm{mL}$ ) to obtain the $\mathrm{IC}_{50}$ value. The mixture of HBV and extract were inoculated onto HepG2-NTCP for 16 hours. Cells were subsequently washed to remove the extract and excess virus. The cells growth medium was replaced every 2 day until day 8. Supernatants were then collected to perform ELISA HBsAg screening (Abnova, HBsAg ELISA kit). Briefly, samples and control treatments at a concentration of $50 \mu \mathrm{l}$ were added into well plates of the kit, then $50 \mu \mathrm{l}$ of anti-HBsAg-peroxidase solution was added. The plate was incubated at $37^{\circ} \mathrm{C}$ for 30 minute and washed with PBS 10 times. To mix the tetramethylbenzidine (TMB) substrate, solution A and $\mathrm{B}$ were added by equal volume of $100 \mu \mathrm{l} /$ well and then incubated for 30 minutes. To stop the reaction, $100 \mu \mathrm{l}$ of $2 \mathrm{~N} \mathrm{H}_{2} \mathrm{SO}_{4}$ were added in each well and absorbance was determined within 30 minutes at $450 / 650$ nm. ${ }^{14}$

\section{HBV post-entry inhibition assay}

Hep38.7-Tet cells were used to assess the effect of extract on the postentry stage of HBV infection. Cells were seeded in a 24 well plate for 24 hours before the assay was performed. Sample was added to the cells at four different concentrations $(200,100,50,25 \mu \mathrm{g} / \mathrm{mL})$ without tetracycline provision, while the positive control was amended with tetracycline to suppress HBV production. In conditions free from tetracycline, Hep38.7-Tet will produce HBV pg RNA and released it into the supernatant of the culture. The plate was incubated for 16 hours then medium free extract was used to wash the extract residue after $16 \mathrm{hr}$. The medium extract was added every 3 days until day 7 . Supernatant was then collected for DNA purification. Real Time (RT)-qPCR was performed to quantify the amount of extracellular HBV DNA in each sample. Briefly, the HBV DNA was purification by centrifugation column filtering (Promega Midi DNA kit purification). The DNA was amplified for real-time quantitative PCR using SYBR Premix Ex Taq (Takara Bio, Shiga, Japan) with specific primers for the HBV genome: Ayw-F (5'-CTCGTGGTGGACTTCTCTC-3') and Ayw-R (5'-AAGATGAGGCATAGCCAGCA-3'). ${ }^{14}$

\section{Cytotoxicity assay}

The cytotoxicity of samples was assessed on selected plants by 3-(4,5-Dimethylthiazol-2-Yl)-2,5-Diphenyltetrazolium Bromide (MTT) assay. Briefly, cells in 96 well plates were treated with various concentrations of crude extracts for 48 hours. The medium was replaced with MTT containing medium and incubated for 4 hours. Insoluble precipitates were dissolved with DMSO and absorbance was measured using a microplate reader. The cell viability percentages 
were compared to the control and facilitation calculation of the $50 \%$ cytotoxic concentration $\left(\mathrm{CC}_{50}\right)$ values. In this study, the cytotoxicity assay was performed both in HepG2-NTCP cells and Hep38.7-tet.

\section{RESULTS}

Anti-HBV screening of entry stage inhibition and cytotoxicity assay of selected active extracts

Among 31 plant extracts evaluated for anti-HBV activity on the viral entry step, two extracts exhibited strong reduction of $\mathrm{HBs}$ production in HepG2-NTCP cells (Figure 1). The extract of P. niruri at a concentration of $100 \mu \mathrm{g} / \mathrm{mL}$ showed $48.2 \%$ inhibition, while the extract of C. xanthorrhiza exhibited $29.0 \%$ inhibition. P. niruri had the strongest antiviral activity with $\mathrm{IC}_{50}$ values of $170.48 \mu \mathrm{g} / \mathrm{mL}$ and $\mathrm{CC}_{50}$ values of $>400 \mu \mathrm{g} / \mathrm{mL}$. In contrast, C. xanthorrhiza extracts showed an IC $_{50}$ value of $270.51 \mu \mathrm{g} / \mathrm{mL}$ and $\mathrm{CC}_{50}$ of $>206.69 \mu \mathrm{g} / \mathrm{mL}$ (Figure 2).

Antiviral HBV screening of post-entry stage inhibition and cytotoxicity assay

To evaluate the active extract in the post-entry step, further analysis was conducted via Hep38.7-Tet cells culture. As can be seen in Figure 3, the post-entry inhibition assay reflected the ability of $P$. niruri to dramatically reduce extracellular HBV DNA levels. Various concentrations were tested and this showed a dose dependent antiviral effect in the post-entry step without any toxicity developing at a dose of $100 \mu \mathrm{g} / \mathrm{mL}$. This result indicated that P. niruri may inhibit HBV replication, assembly, and virion release. The cytotoxicity of $P$. niruri extract in Hep38.7-tet showed did not suppress the viability of cells with a $\mathrm{CC}_{50}$ value exceeding $274.51 \mu \mathrm{g} / \mathrm{mL}$. In contrast, the extract of $C$. xanthorrhiza inhibited post-entry stage infection with a $30 \%$ reduction of HBV DNA levels at a concentration of $50 \mu \mathrm{g} / \mathrm{mL}$. Furthermore, $C$. xanthorrhiza exhibits greater toxicity than P. niruri extract (Figure 3)

\section{DISCUSSION}

Medicinal plants are promising candidates for drug discovery due to their interesting chemical metabolites. It has been previously reported that various compounds isolated from these plants display promising bioactivity. ${ }^{16} \mathrm{~A}$ number of medicinal plants from various countries have been tested for anti-HBV to find potential candidates for anti-HBV drug development. The goal of HBV therapy is to prevent the progression of chronic hepatitis B to cirrhosis, end-stage liver disease, hepatocellular carcinoma and death. ${ }^{17}$ It has also been postulated that some medicinal plants used in Traditional Chinese Medicine exhibit anti-HBV activity. ${ }^{13}$ Several plants native to the Arabian Peninsula: Guiera senegalensis, Pulicia crispa, Coccinea grandis, Fumaria parviflora, Capparis decidua, Corallocarpus epigeus, Indigofera caerulea, Abutilon figarianum and Acacia oerfota have also been found to possess anti-HBV activity by inhibiting hepatitis B surface antigen ( $\mathrm{HBsAg}$ ) and hepatitis $\mathrm{B} e$ antigen (HBeAg) in the cell culture supernatant. ${ }^{18}$ Our previous study also reported that Cananga odorata exhibited strong inhibition of the hepatitis B virus in Hep38.7-Tet and HepG2-NTCP cells. ${ }^{14}$

In this study we evaluated a number of medicinal plants for anti-HBV which have been reported to show anti-viral activity. The plants were selected based on empirical used and preclinical empirical studies. We examined the abilities of 31 Indonesian medicinal plants to inhibit the entry step of HBV into HepG2-NTCP and the levels of extracellular

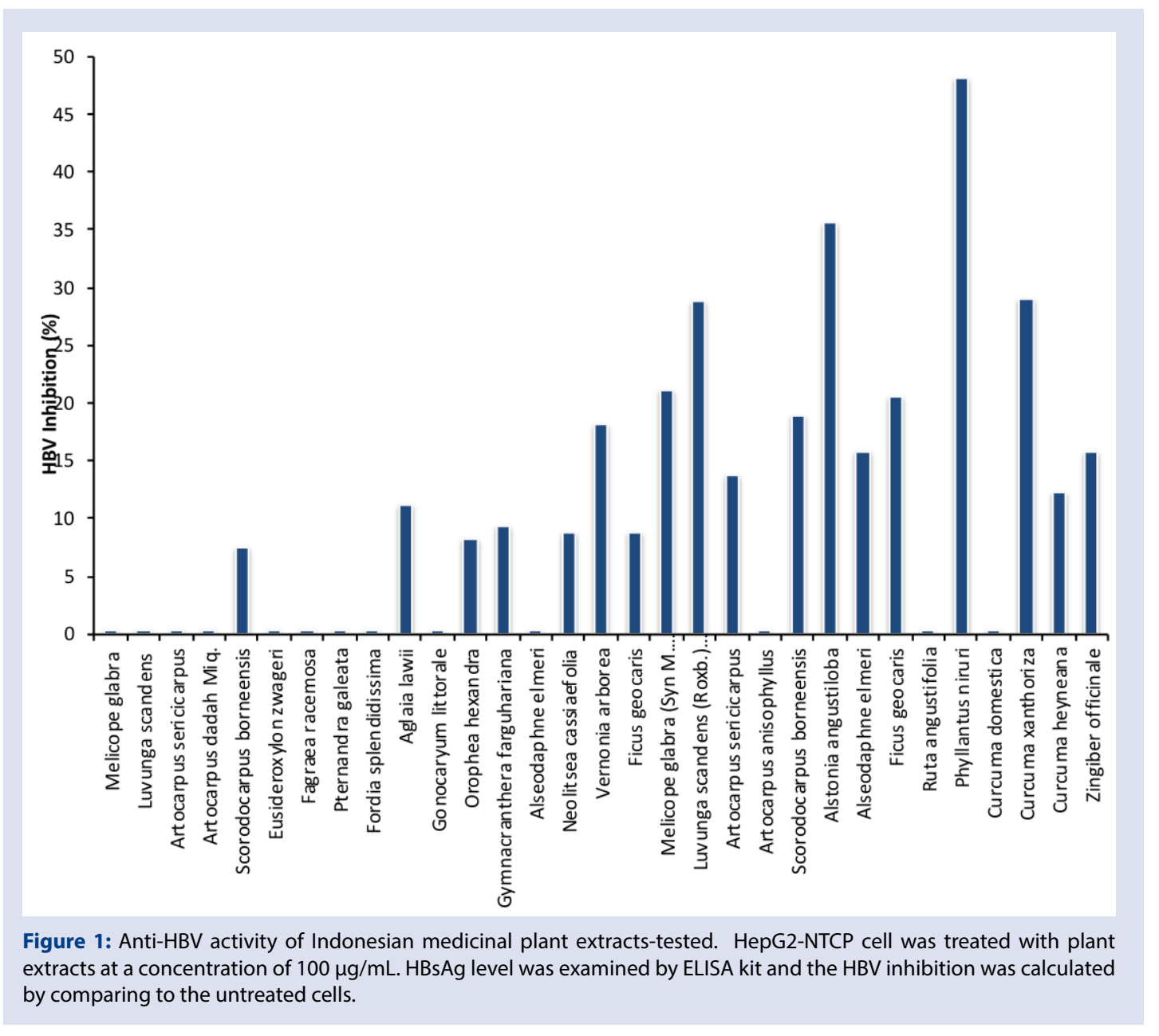



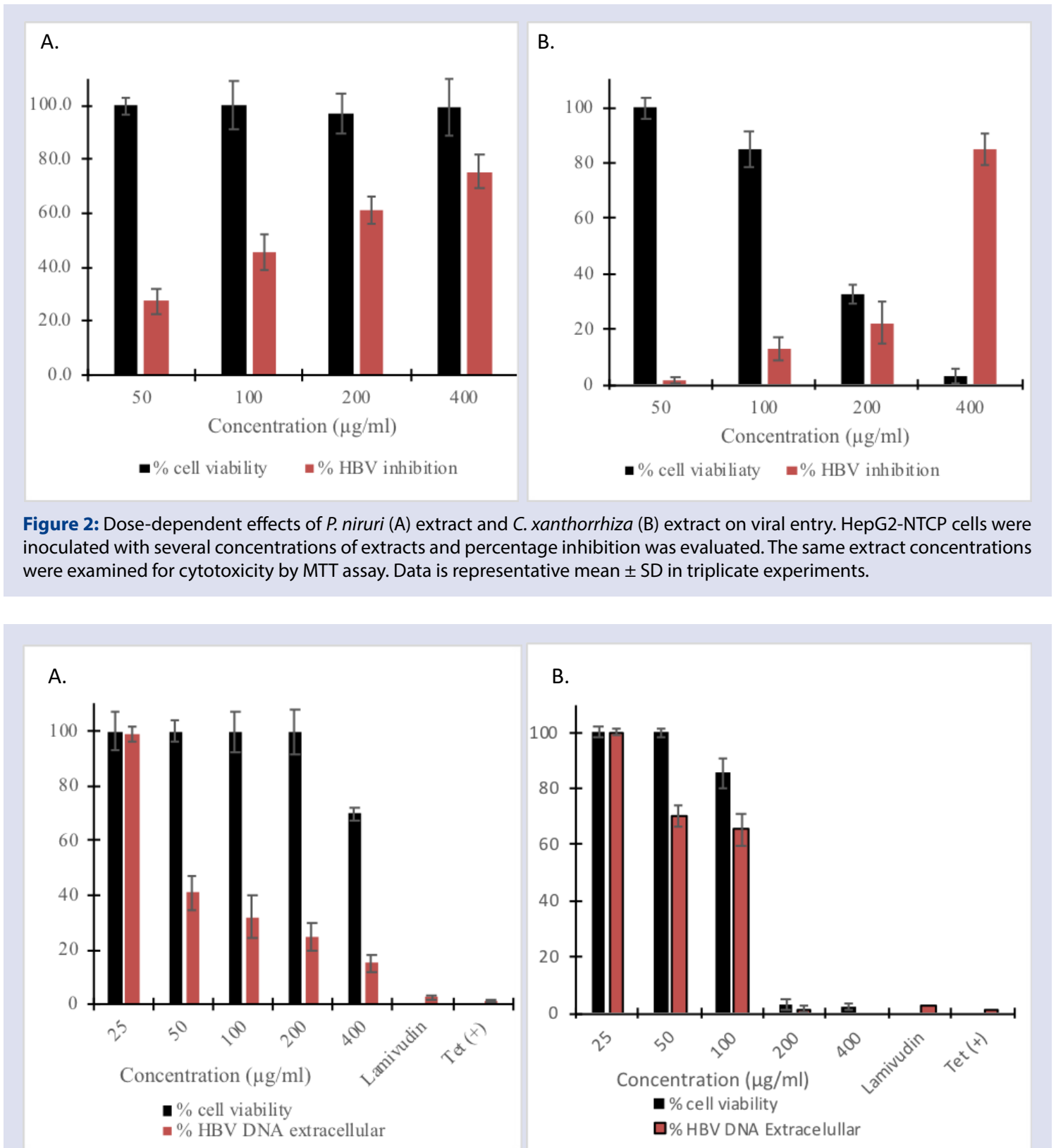

Figure 3: Dose-dependent effects of $P$. niruri (A) and C. xanthorrhiza (B) on post-entry steps. Hep38.7-Tet cells were inoculated with several concentrations of extract; the HBV DNA was quantified using IC-RT-qPCR assay and percentage inhibition was calculated by comparing to the untreated control. Lamivudine is served as a positif control. The same extract concentrations were examined for cytotoxicity by MTT assay. Data is representative mean \pm SD in triplicate experiments.

HBV DNA on HepAD38.2 cells. In the HBV life cycle, after infecting hepatocyte cells, the virus will undergo several steps, including, attachment, endocytosis, and release of capsid. Following this, the relaxed circular HBV DNA genome is converted into covalently closed circular DNA (cccDNA). The replication process includes transcription, translation, encapsidation, reverse transcription, DNA synthesis, budding the virion and release. NTCP is a receptor for HBV entry, which is overexpressed in the HepG2-NTCP cell line used to evaluate antiHBV activity in the entry step ${ }^{15}$. The other cell line, Hep38.7-Tet, was a tetracycline inducible hepatitis B virus expressing cell line. Replication of the virus can be induced in this cell line and, therefore, it is suitable for detecting inhibition in the post-entry step as well as replication of virus. ${ }^{19}$ Our research demonstrated that the extracts of $P$. niruri and $C$. xanthorrhiza exhibited anti-HBV activities of a greater magnitude than the other plant extracts tested. P. niruri inhibited viral entry with an $\mathrm{IC}_{50}$ value of $170.5 \mu \mathrm{g} / \mathrm{ml}$ and $\mathrm{CC}_{50}$ value of $>400 \mu \mathrm{g} / \mathrm{mL}$ and inhibited postentry steps (extracellular HBV DNA was reduced reduced) without exhibiting cytotoxicity. In contrast, C. xanthorhiza showed a toxic effect in HepG2-NTCP and Hep38.7-Tet cells at a concentration of $200 \mu \mathrm{g} / \mathrm{ml}$ and did not inhibit HBV replication in Hep38.7-Tet cells.

P. niruri is a plant that is found in many areas across tropical and subtropical regions. The genus of Phyllanthus (Euphorbiaceae) has been used for various traditional medicines in many countries, including in Indonesia. It has been reported to exhibit varied and interesting biological activities, including stomachic, diuretic, febrifuge, deobstruent, and antiseptic activity and has used in effective remedies for hepatopathy. ${ }^{20}$ The various species of the Phyllanthus family, such as the P. amarus, $P$. niruri, $P$. urinaria, and $P$. orbicularis, have been reported to inhibit a broad spectrum of viruses. Previous work showed that these plants may 
inhibit human immunodeficiency virus (HIV) and herpes simplex virus (HSV). ${ }^{21,22}$ It has been reported that extracts from Phyllanthus species have a positive effect on the antiviral activity and serology response of HBsAg in HBV carriers. ${ }^{23}, 24$ It was also demonstrated that the extract of Phyllanthus amarus suppresses hepatitis B virus by interrupting the interaction between HBV enhancer I and cellular transcription factors, resulting in an inhibition of polymerase activity and mRNA transcription. ${ }^{25,26}$ Our findings demonstrate a different mechanism of anti-HBV activity for $P$. niruri.

P. niruri contains numerous compounds, including alkaloids, flavonoids, lignans, phenols, and terpenes, which display equally varied biological activities including antiviral activity. Phyllanthin and hypophyllanthin are the lignin compounds that were found to be major compounds of $P$. niruri. ${ }^{27}$ Phyllanthin was predicted to interact with the entry receptors of the hepatitis virus and exhibit hepatoprotective activities. Niranthin and hinokinin isolated from P. amarus strongly inhibit hepatitis $\mathrm{B}$ activity while Corilagin was reported to block HCV NS3 protease and NS5B RNA-dependent-RNA-polymerase. ${ }^{28,29}$

In contrast to P. niruri, C. xanthorrhiza was widely used in many traditional medicines as an anticancer, anti-microbial, antiinflammatory, anti-oxidant, anti-hyperglycemic, anti-hypertensive, antiplatelet and nephroprotective. ${ }^{30}$.The ethanol extracts of C. xanthorrhiza have been demonstrated to reduce fatty liver symptom and inhibit alanine transaminase (ALT), aspartate transaminase (AST), alkaline phosphatase (ALP) and protein content. ${ }^{31}$ The isolated compound from the fresh rizhome, xanthorrizol, expresses antimicrobial activity against pathogenic bacteria and fungi. ${ }^{31-33}$ Extracts of C. xanthorrhiza have previously been demonstrated to exhibit anti-hepatitis $C$ virus activity. ${ }^{34}$ Our study showed C. xanthorrhiza has marginal inhibitory effect on HBV entry step.

\section{CONCLUSION}

Among 31 plant extracts, $P$. niruri exhibited the greatest anti-HBV activity on both the viral entry step and viral replication. This plant is promising candidate for anti-HBV drug development.

\section{CONFLICTS OF INTEREST}

None.

\section{ACKNOWLEDGEMENTS}

We thank Dr. Koichi Watashi and Dr. Takaji Wakita (National Institute of Infectious Diseases, Tokyo, Japan) for providing Hep38.7-Tet and HepG2-NTCP cells. This work was supported by Research Institute and Inovation, Airlangga University through Riset Mandat Grant, FY2018 LIPI-JSPS bilateral joint research project, and Inamori Foundation.

\section{REFERENCES}

1. Venkatakrishnan B, Zlotnick A. The Structural Biology of Hepatitis B Virus: Form and Function. Annual Review of Virology. 2016;3:429-51.

2. Kanda T, Goto T, Hirotsu Y, Moriyama M, Omata M. Molecular Mechanisms Driving Progression of Liver Cirrhosis towards Hepatocellular Carcinoma in Chronic Hepatitis B and C Infections: A Review. International Journal of Molecular Sciences. 2019;20.

3. MacLachlan JH, Cowie BC. Hepatitis B virus epidemiology. Cold Spring Harb Perspect Med. 2015;5.

4. Tufon KA, Meriki HD, Kwenti TE, Tony NJ, Malika E, Bolimo AF, et al. HBV Transmission Risk Assessment in Healthcare Workers, Household and Sexual Contacts of HBV Infected Patients in the Southwest Region of Cameroon. Oman Med J. 2019;34:313-21.

5. Das S, Ramakrishnan K, Behera SK, Ganesapandian M, Xavier AS, Selvarajan S. Hepatitis B Vaccine and Immunoglobulin: Key Concepts. Journal of Clinical and Translational Hepatology. 2019;7:165-71.

6. Lok ASF. Hepatitis B Treatment: What We Know Now and What Remains to Be Researched. Hepatol Commun. 2019;3:11.
7. Koumbi L. Current and future antiviral drug therapies of hepatitis B chronic infection. World Journal of Hepatology 2015;7:1030-40.

8. Mintah SO, Agyei TA, Archer MA, Junior PA, Boamah D, Kumadoh D, et al Medicinal Plants for Treatment of Prevalent Diseases. IntechOpen Limited, 2018.

9. Kim HJ, Yoo HS, Kim JC, Park CS, Choi MS, Kim M, et al. Antiviral effect of Curcuma longa Linn extract against hepatitis B virus replication. Journal of Ethnopharmacology. 2009;124:189-96.

10. Li YQ, Wang SF. Anti-hepatitis B activities of ganoderic acid from Ganoderma lucidum. Biotechnology Letters. 2006;28:837-41.

11. Wei PH, Wu SZ, Mu XM, Xu B, Su QJ, Wei JL, et al. Effect of alcohol extract of Acanthus ilicifolius L. on anti-duck hepatitis $B$ virus and protection of liver Journal of Ethnopharmacology. 2015;160:1-5.

12. Han $Y Q$, Huang ZM, Yang $X B$, Liu HZ, Wu GX. In vivo and in vitro antihepatitis $B$ virus activity of total phenolics from Oenanthe javanica. Journal of Ethnopharmacology 2008;118:148-53.

13. Geng C-A, Chen J-J. The Progress of Anti-HBV Constituents from Medicinal Plants in China. Nat Prod Bioprospect. 2018;8:227-44.

14. Indrasetiawan P, Aoki-Utsubo C, Hanafi M, Hartati S, Wahyuni TS, Kameoka M, et al. Antiviral Activity of Cananga odorata Against Hepatitis B Virus. The Kobe Journal of Medical Sciences. 2019;65:E71-e79.

15. Iwamoto M, Watashi K, Tsukuda S, Aly HH, Fukasawa M, Fujimoto A, et al. Evaluation and identification of hepatitis $B$ virus entry inhibitors using HepG2 cells overexpressing a membrane transporter NTCP. Biochemical and Biophysical Research Communications. 2014;443:808-13.

16. Siddiqui MH, Alamri SA, Al-Whaibi MH, Hussain Z, Ali HM, El-Zaidy ME. A minireview of anti-hepatitis $B$ virus activity of medicinal plants. Biotechnology \& Biotechnological Equipment 2017;31:9-15.

17. European Association for the Study of the L. EASL Clinical Practice Guidelines: Management of chronic hepatitis B virus infection. Journal of Hepatology. 2012;57:167-85

18. Arbab AH, Parvez MK, Al-Dosari MS and Al-Rehaily AJ. In vitro evaluation of novel antiviral activities of 60 medicinal plants extracts against hepatitis $B$ virus. Experimental and Therapeutic Medicine. 2017;14:626-34.

19. Ogura N, Watashi K, Noguchi T, Wakita T. Formation of covalently closed circular DNA in Hep38.7-Tet cells, a tetracycline inducible hepatitis B virus expression cell line. Biochemical and Biophysical Research Communications. 2014;452:315-21

20. Mao X, Wu L-F, Guo H-L, Chen W-J, Cui Y-P, Qi Q, et al. The Genus Phyllanthus: An Ethnopharmacological, Phytochemical, and Pharmacological Review. Evidencebased Complementary and Alternative Medicine : eCAM 2016;2016:75849527584952.

21. Forero JE, Avila L, Taborda N, Tabares P, López A, Torres F, et al. In vitro antiinfluenza screening of several Euphorbiaceae species: Structure of a bioactive Cyanoglucoside from Codiaeum variegatum. Phytochemistry. 2008;69:2815-9.

22. Tan WC, Jaganath IB, Manikam R, Sekaran SD. Evaluation of Antiviral Activities of Four Local Malaysian Phyllanthus Species against Herpes Simplex Viruses and Possible Antiviral Target. International Journal of Medical Sciences. 2013; 10:1817-29

23. Liu J, Lin H, Mclntosh H. Genus Phyllanthus for chronic hepatitis B virus infection: a systematic review. Journal of Viral Hepatitis. 2001;8:358-66.

24. Yeh S-F, Hong C-Y, Huang Y-L, Liu T-Y, Choo K-B, Chou C-K. Effect of an extract from Phyllanthus amarus on hepatitis $B$ surface antigen gene expression in human hepatoma cells. Antiviral Research. 1993;20:185-92.

25. Ott M, Thyagarajan SP, Gupta S. Phyllanthus amarus suppresses hepatitis $B$ virus by interrupting interactions between HBV enhancer I and cellular transcription factors. European Journal of Clinical Investigation 1997;27:908-15

26. Lee CD, Ott M, Thyagarajan SP, Shafritz DA, Burk RD, Gupta S. Phyllanthus amarus down-regulates hepatitis $B$ virus mRNA transcription and replication. European Journal of Clinical Investigation. 1996;26:1069-76.

27. Calixto JB, Santos AR, Cechinel Filho V, Yunes RA. A review of the plants of the genus Phyllanthus: their chemistry, pharmacology, and therapeutic potential. Medicinal Research Reviews. 1998;18:225-58.

28. Reddy BU, Mullick R, Kumar A, Sharma G, Bag P, Roy CL, et al. A natural small molecule inhibitor corilagin blocks HCV replication and modulates oxidative stress to reduce liver damage. Antiviral Research. 2018;150:47-59.

29. Huang RL, Huang YL, Ou JC, Chen CC, Hsu FL, Chang C. Screening of 25 compounds isolated from Phyllanthus species for anti-human hepatitis $B$ virus in vitro. Phytotherapy Research: PTR. 2003;17:449-53.

30. Oon SF, Nallappan M, Tee TT, Shohaimi S, Kassim NK, Sa'ariwijaya MSF, et al. Xanthorrhizol: a review of its pharmacological activities and anticancer properties. Cancer Cell Int. 2015;15:100-100.

31. Hwang JK, Shim JS, Baek NI, Pyun YR. Xanthorrhizol: a potential antibacterial agent from Curcuma xanthorrhiza against Streptococcus mutans. Planta Medica. 2000;66:196-7. 
32. Mary HPA, Susheela GK, Jayasree S, Nizzy AM, Rajagopal B, Jeeva S. Phytochemical characterization and antimicrobial activity of Curcuma xanthorrhiza Roxb. Asian Pacific Journal of Tropical Biomedicine. 2012;2:S63740.

33. Lee LY, Shim JS, Rukayadi Y, Hwang JK. Antibacterial activity of xanthorrhizol isolated from Curcuma xanthorrhiza Roxb. against foodborne pathogens. Journal of Food Protection. 2008;71:1926-30
34. Wahyuni TS, permatasari AA, Widiandani T, Fuad A, Widyawaruyanti A, AokiUtsubo C, et al. Antiviral Activities of Curcuma Genus against Hepatitis C Virus. Natural product communications 2018; 13: 1934578X1801301204. DOI: 10.1177/1934578X1801301204.

\section{GRAPHICAL ABSTRACT}

\begin{tabular}{|c|c|c|}
\hline \multirow{2}{*}{\multicolumn{3}{|c|}{ No Species Name Family }} \\
\hline \multirow{2}{*}{\multicolumn{3}{|c|}{$\begin{array}{l}\text { Dichloromethane extract of leaves (Balikpapan sample) } \\
\end{array}$}} \\
\hline & & Rutacease \\
\hline 2 & Luvunga scandens (Roxb.) Wight & Rutaceae \\
\hline & Artocarpus sericicarpus & Moraceae \\
\hline 4 & Artocarpus anisophylhus & Moraceae \\
\hline 5 & Artocarpus dadah Miq. & Moraceae \\
\hline 6 & Scorodocarpus borneensis & Olacaceae \\
\hline & Eusideroxylon zwageri & Lauraceae \\
\hline 8 & Fagraea racemosa & Loganiaceae \\
\hline 9 & Pternandra galeata & Melastomataceae \\
\hline 10 & Goniothalamus macrophyllus & Annonaceae \\
\hline 11 & Fordia splendidissima & Fabaceae \\
\hline 12 & Garcinia paviffora & Clusiaceae \\
\hline 13 & Aglaia lawii & Meliaceae \\
\hline 14 & Cratoxyhom swomatranum & Hypericaceae \\
\hline 15 & Gonocarywm littorale & Icacinaceae \\
\hline 16 & Orophea hexanara & Lauraceae \\
\hline 17 & Alstonia angustiloba & Apocynaceae \\
\hline 18 & Gymnacranther a far guhariana & Lauraceae \\
\hline 19 & Alseodaphne elmeri & Lauraceae \\
\hline 20 & Neolitsea cassiaefolia & Lauraceae \\
\hline 21 & Vernonia arborea & Asteraceae \\
\hline & Ficus geocaris & Moraceae \\
\hline \multirow{2}{*}{\multicolumn{3}{|c|}{ Dichloromethane extract of stem bark (Balikpapan Sample) }} \\
\hline & & Rutacease \\
\hline 24 & Luvunga scandens (Roxb.) Wight & Rutaceae \\
\hline & Artocarpus sericicarpus & Moraceae \\
\hline 26 & Artocarpus anisophyllus & Moraceae \\
\hline 27 & Scorodocarpus borneensis & Olaccaceae \\
\hline & Cratoxylum sumatranum & Hypericaceae \\
\hline & Alstonia angustiloba & Apocynaceae \\
\hline & Alseodaphne elmeri & Lauraceae \\
\hline & Ficus geocaris & Moraceae \\
\hline \multicolumn{3}{|c|}{ Ethanol extract (East Java Sample) } \\
\hline & Rula anglustifolla (leaves) & Kutaceae \\
\hline & Phyllantus niruri (herbs) & Euphorbiaceae \\
\hline & Curcuma domestica (Rhizome) & Zingiberaceae \\
\hline & Curcuma xanthoriza (Rhizome) & Zingiberaceae \\
\hline & Curcuma heyneana (Rhizome) & Zingiberaceae \\
\hline & Zingiber officinale (Rhizome) & \\
\hline
\end{tabular}

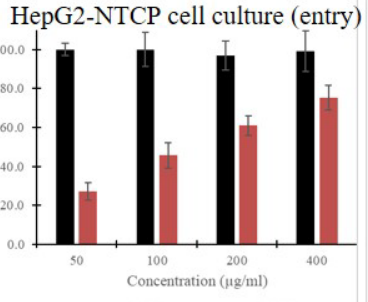

- $\%$ cell viability $\quad \%$ HBV inhibitin

Phyllanthus niruri inhibited viral entry $\left(\mathrm{IC}_{50}\right.$ value of 170.5

Phyllanthus niruri inhibited viral entry $\left(\mathrm{IC}_{50}\right.$ value of 170
$\mu \mathrm{g} / \mathrm{ml}$ and $\mathrm{CC}_{50}$ value of $\left.>400 \mu \mathrm{g} / \mathrm{mL}\right)$ and Replication step

Good Candidate for

C) HBV drug

development

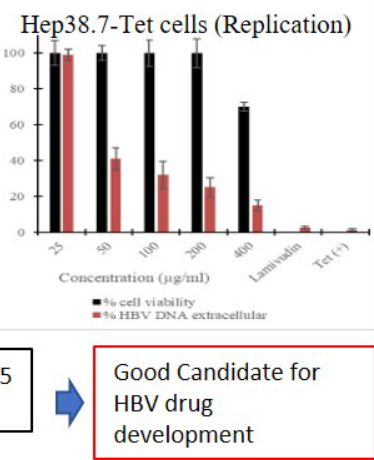

Hep38.7-Tet cells (Replication)

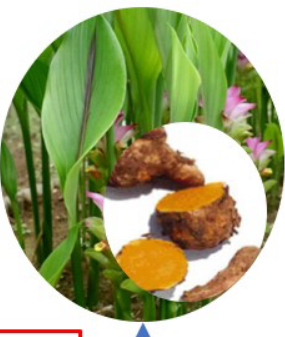

HepG2-NTCP cell culture (entry)

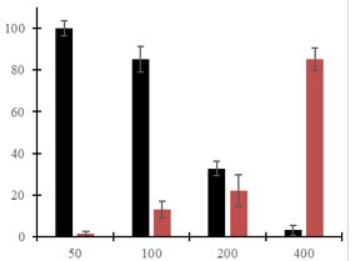

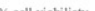

Curcuma xanthorrhiza, inhibit entry $\left(\mathrm{IC}_{50} 270.51 \mu \mathrm{g} / \mathrm{mL}\right.$ and $\mathrm{CC}_{50}$ of $>206.69 \mu \mathrm{g} /$ ) and a concentration of $200 \mu \mathrm{g} / \mathrm{ml}$ did not inhibit HBV replication.

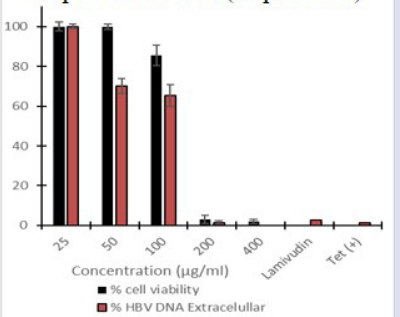

\section{ABOUT AUTHORS}

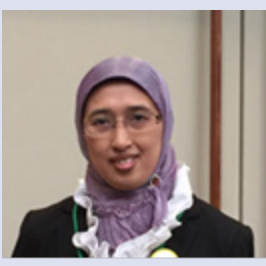

Tutik Sri Wahyuni , PhD. is a lecturer at Department of Pharmacognosy and phytochemistry Faculty of Pharmacy and a researcher in at Natural Product Medicine Research and Development (NPMRD), Institute of Tropical Disease, Universitas Airlangga. She took her PHD at Kobe University, Graduate School of Medicine2 and studied on anti-hepatitis C virus activities of medicinal plants and its metabolites. Now, she focusses on drug development for hepatitis virus infection of medicinal plants.

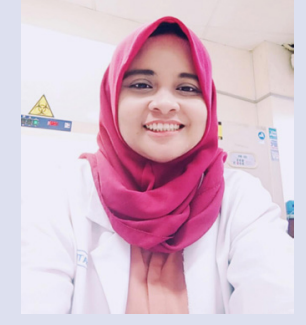

Adita Ayu Permanasari, MSc, is a researcher in Institute of Tropical Disease, Universitas Airlangga, Indonesia. She graduated in Master of Biology from Faculty of Science and Technology, Universitas Airlangga. She is currently work on antihepatitis virus cell culture and its mechanism of action. Some studies of hepatitis viruses have been published in some international scientific journals. 


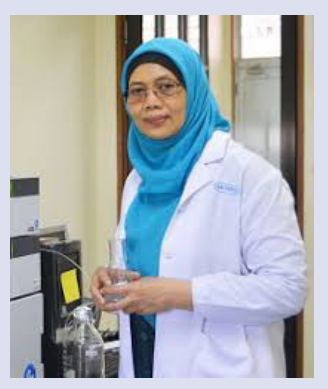

Dr. Aty Widyawaruyanti is a lecturer at Faculty of Pharmacy, Universitas Airlangga and researcher at Natural Product Medicine Research and Development (NPMRD), Institute of Tropical Disease, Universitas Airlangga. She obtained her bachelor degree in Pharmacy at Faculty of Pharmacy, Padjajaran University. She was further persued her Master and Doctoral degree at Faculty of Pharmacy, Universitas Airlangga. Her research is focuses on drug discovery from bioactive natural products especially drug discovery for antimalarial drugs and other infectious diseases.

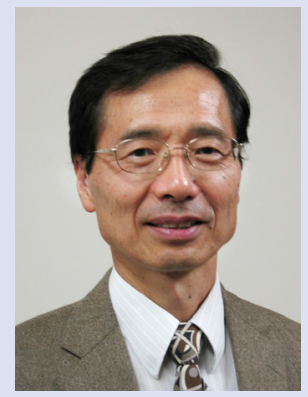

Professor Hak Hotta. Professor at Faculty of Nutrition and Clinical Dietetics, Konan Women's University

Professor Emeritus at Kobe University (Medicine)

M.D. (Osaka University School of Medicine)

Ph.D. (Kobe University Graduate School of Medicine)

Professional Career:

Visiting Scientist at Wistar Institute in 1986-1987

Professor and Chair (Microbiology) at Kobe University School of Medicine in 1994-2015

Endowed Professor at Kobe University Graduate School of Health Sciences in 2015-2018

Professor at Konan Women's University since 2018

Concurrent International Professional Career

Adjunct Professor at University of Indonesia

Honorary Professor at Airlangga University

\section{Chie Aoki-Utsubo, Ph.D}

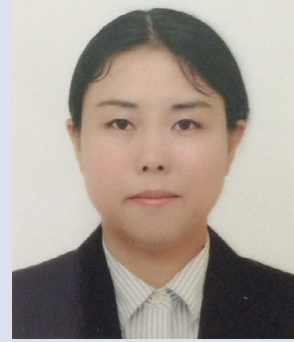

Graduated from School of Pharmacy, Nihon University in 2002 and completed my Ph.D. from the University of Shizuoka, Japan in 2007. The doctoral thesis was focused on identification and characterization of the carbohydrate molecule which is associated with entry of Dengue virus type 2 to the mammalian cells. Then, I worked on development of new system for screening of anti-hepatitis $\mathrm{C}$ virus (HCV) drugs as a post-doctoral researcher (2007-2010) and screening of anti-HCV substances from Indonesian medicinal plants as a project assistant professor (2010-2014). Since 2015, I have worked as an associate professor at Kobe University Graduate School of Health Sciences, Japan and studied on antiviral mechanism of natural compounds exhibiting antiviral activities against hepatitis B, C, and dengue viruses.

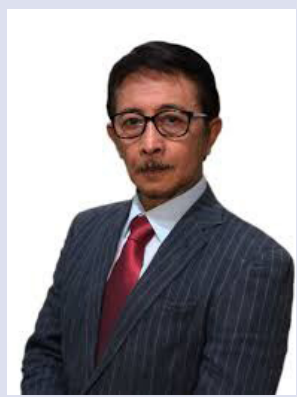

Professor Achmad Fuad Hafid is currently vice-director of Institute of Tropical Disease, Universitas Airlangga. He is a lecturer at Faculty of Pharmacy, Universitas Airlangga and a researcher as well. His acquired a Professor with expertise in the fields of phytochemistry and bioactive natural product discovery for therapeutics applications.

Cite this article: Wahyuni TS, Permanasari AA, Widyawaruyanti A, Hotta H, Aoki-Utsubo C, Hafid. Antiviral Activity of Indonesian Medicinal Plants against Hepatitis B Virus. Pharmacogn J. 2020;12(5):1108-14. 